\title{
DESIGN PROCESS OF CSTR FOR PRODUCTION OF FURFURALDEHYDE
}

\author{
Wordu A. A ${ }^{1}$, Anthony O.J ${ }^{2}$ \\ ${ }^{I}$ Department of Chemical/Petrochemical Engineering, University of Science and Technology, Nkpolu, Porthacourt, \\ Rivers State, Nigeria \\ ${ }^{2}$ Department of Chemical/Petrochemical Engineering, University of Science and Technology, Nkpolu, Porthacourt, \\ Rivers State, Nigeria
}

\begin{abstract}
A realistic academic cum industrial Isothermal continuous stirred tank reactor design, feed rate $11.51 \mathrm{kgs}^{-1}$ furfuraldehyde productions is presented. Principles of material balance and heat generated per unit volume equations were performed on the reactor system to derive model equations applied in obtaining the reactor functional parameters. Mechanical concepts of the reactor and the economics of the design were considered. The functional parameters of the reactor were computed using efficient mat-lab program version 7.7 as shown. The hydrolysis and dehydration reaction of xylan and xylose respectively to furfural is endothermic; a heating jacket is incorporated to account for the supply and maintenance of heat liberated.
\end{abstract}

Keywords: Isothermal-CSTR, furfuradehyde, material-energy equations, mechanical aspects, functional-parameters.

\section{INTRODUCTION}

Design is a creative activity that integrates the elements of art and science to create something new or retrofit for existence. Some agricultural wastes [e.g peanuts seed shell] in Nigeria were subjected to titrimetric analysis for presence of furfural and results were Positive to varying degrees [Wordu and Akaranta, 1989]. The study gave obvious contributions to the local content of the economy [Nigerian Local Content Act, 2004], by designing full-scale reactor for the production of furfural.

Continuous Stirred Tank Reactor design is complemented with thermodynamics, chemical kinetics, fluid mechanics, heat transfer, mass transfer and economics as well as mechanical aspects. The perfect mixing is attained by the effect of a stirrer in the reactor which ensures contents of the reactor are properly mixed so that the temperature and concentration of the content are the same at the product stream and in the reactor. Furfural ( i.e a heterocyclic compound with an aldehyde group chemical formula is $\mathrm{C}_{5} \mathrm{H}_{4} \mathrm{O}_{2}$ ) is an organic compound derived from variety of agricultural by-products including corncobs, Oat hulls, wheat bran's, wood, sugarcane bagasse.

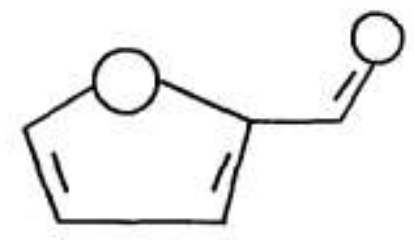

Fig1: Molecular structure, IUPAC name furar-2carbaldehyde; other names are furan, furfuraldehyde, 2furaldehyde, pyromucic aldehyde.
Furfural is produced from polysaccharide hemi-cellulose, (or pentonsans) a polymer of sugar by biphasic reaction with $\mathrm{H}_{2} \mathrm{SO}_{4}$ in the present of heat (Rong et al, 2012). The hemi cellulose is heated in the presence of $\mathrm{H}_{2} \mathrm{SO}_{4}$, it undergoes hydrolysis to yield sugar of five carbon atom called xylose (pentose). The xylose is heated in the presence of $\mathrm{H}_{2} \mathrm{SO}_{4}$ at the same condition; it dehydrates or undergoes cyclodehydration losing three water molecules to become furfural.The furfural and water evaporates out and are separated upon condensation.

\section{MATERIALS AND METHOD}

\subsection{Rate Law, Kinetics and Process Chemistry}

Furfural is produced from polysaccharide hemi-cellulose, (or pentonsans) a polymer of sugar by biphasic reaction with $\mathrm{H}_{2} \mathrm{SO}_{4}$ in the present of heat (Rong et al, 2012). The hemi cellulose is heated in the presence of $\mathrm{H}_{2} \mathrm{SO}_{4}$, it undergoes hydrolysis to yield sugar of five carbon atom called xylose (pentose). The xylose is heated in the presence of $\mathrm{H}_{2} \mathrm{SO}_{4}$ at the same condition; it dehydrates or undergoes cyclodehydration losing three water molecules to become furfural.

The furfural and water evaporates out and are separated upon condensation

The reaction that yield furfural from the above mentioned materials in introduction is a series first order reaction under same condition of a mineral acid and heat which are hydrolysis of the pentosans to pentose and dehydration of the pentose to furfural [4] 


\section{Chemical Reaction of Furfural Production}

Pentonsans + water $\stackrel{\Delta, H c l}{\longrightarrow}$ pentose

$$
\begin{aligned}
& \mathrm{C}_{5} \mathrm{H}_{8} \mathrm{O}_{4}+\mathrm{H}_{2} \mathrm{O} \stackrel{\Delta_{1} \mathrm{Hcl}}{\longrightarrow} \mathrm{C}_{5} \mathrm{H}_{10} \mathrm{O}_{5} \\
& \text { Pentose } \stackrel{\Delta, \mathrm{Hcl}}{\longrightarrow} \text { furfural + water }
\end{aligned}
$$

$$
\mathrm{C}_{5} \mathrm{H}_{10} \mathrm{O}_{5} \stackrel{\Delta, \mathrm{Hcl}}{\longrightarrow} \mathrm{C}_{5} \mathrm{H}_{4} \mathrm{O}_{2}+3 \mathrm{H}_{2} \mathrm{O}
$$

\section{Kinetic Scheme for Furfural Production [4], [7]}

Pentosan $\stackrel{k_{1}}{\longrightarrow}$ pentose $\stackrel{k_{2}}{\longrightarrow}$ furfural

Let, Pentosan $=\mathrm{A}$, Pentose $=\mathrm{B}$, Furfural $=\mathrm{C}$

Rate of Pentosan hydrolysis: ${ }^{r_{X y l a n}}=\frac{d C_{A}}{d t}=-k_{1} C_{A}$

Rate of Pentose reaction [9]: $\quad r_{\text {Xylose }}=\frac{d C_{B}}{d t}=$

$k_{1} C_{A}-k_{2} C_{B}$

Rate of furfural formation: $r_{\text {furfural }}=\frac{d C_{C}}{d t}=k_{2} C_{B}$

$k_{i}=A_{0, i}\left[H_{2} S O_{4} \%\right]^{m_{i}} \ell \frac{-E_{A, i}}{R T}$

$r_{i}= \pm k_{i} C_{i}[9]$

\section{METHOD}

\subsection{Development of Reactor Model}

From material balance equation which applies the principle of mass conservation is the starting point of reactor design. The principle states that:

Rate of reactant flow into element of volume $=$ Rate of reactant flow out of element of volume + Rate of reactant loss due to chemical reaction within element of volume + Rate of accumulation of reactant in element of volume [9].

Rate of reactant flow into element volume $=F_{i, o}$

Rate of reactant flow out of element of volume (with respect to fractional conversion $)=F_{i, o}\left(1-X_{i}\right)$

Rate of accumulation of reactant within element of volume $=\frac{d}{d t}\left(C_{i} V\right)$
Rate of reactants loss due to chemical reaction $=\left(-r_{i}\right) V_{R}$

Substituting all the above into

$$
\begin{aligned}
& F_{i, o}=F_{i, o}\left(1-X_{i}\right)+\left(-r_{i}\right) V_{R}+\frac{d}{d t}\left(C_{i} V\right) \\
& F_{A, O}=F_{A, O}\left(1-X_{A}\right)+\left(-r_{A}\right) V_{R}+\frac{d}{d t}\left(C_{A} V\right)
\end{aligned}
$$

Assumptions for the reactor;

- $\quad$ The feed is well stirred or properly mixed.

- Neglecting the inflow rate of catalyst and solvent.

- Steady state operation.

- Isothermal and non-adiabatic system.

- Constant density system.

- Cylindrical tank with hemispherical head.

Applying the assumptions where necessary into equation (1) gives;

$$
F_{A, O}=F_{A, O}\left(1-X_{A}\right)+\left(-r_{A}\right) V_{R}
$$

$$
F_{A, O}=F_{A, O}-F_{A, O} X_{A}+\left(-r_{A}\right) V_{R} V_{R}=\frac{F_{A, O} X_{A}}{\left(-r_{A}\right)}
$$

Taking the rate with respect to furfural formation

$-r_{A}=r_{C}=k_{2} C_{B}$

Where: $C_{B}=C_{B, O}\left(1-X_{A}\right)$

for constant density system [9]

$C_{B, O}=C_{A}$ Since it's a series reaction

Substituting (9) into (8):

$$
-r_{A}=k_{2} C_{A}\left(1-X_{A}\right)
$$

Substituting (3) into (4) :

$$
V_{R}=\frac{F_{A, O} X_{A}}{k_{2} C_{A}\left(1-X_{A}\right)}
$$

$V_{R}=$ Volume of the reactor $\left(\mathrm{m}^{3}\right)$

\subsection{Length of Reactor $L_{R}$}

Volume of a cylinder is given as: 
$V=\pi r^{2} L$

Equating (12) to (11) :

$\pi r^{2} H=\frac{F_{A, O} X_{A}}{k_{2} C_{A}\left(1-X_{A}\right)}, \quad H_{R}=\frac{F_{A, O} X_{A}}{\pi r^{2} k_{2} C_{A}\left(1-X_{A}\right)}$

$L_{R}=$ Length of reactor $(m)$

\subsection{Dimension of Reactor Head}

$L_{H}=\frac{D_{R}}{2}$

$V_{H}=\pi \frac{D_{R}{ }^{3}}{12}$

Where: $V_{H}=$ Volume of reactor head $\left(m^{3}\right), L_{H}=$ Length of reactor head $(m)$

\subsection{Resident time distribution (RTD) Space time}

$(\tau)$

$\tau=\frac{V_{R}}{v_{o}}$

$v_{o}=\frac{F_{A, O}}{C_{A}}$

Substituting (11) and (9) into (5):

$\tau=\frac{X_{A}}{k_{2}\left(1-X_{A}\right)}$

3.5 Space-Velocity $(s)$

$$
S_{v}=\frac{1}{\tau}
$$

Substituting (18) into (19):

$$
S_{v}=\frac{k_{2}\left(1-X_{A}\right)}{X_{A}}
$$

\subsection{Heat Generation per Volume of Reactor}

$$
q_{R}=\frac{Q}{V_{R}}
$$

$$
Q=\left(\Delta H_{r}\right) F_{A, O} X_{A}
$$

Substituting (22) and (11) into (21):

$$
q_{R}=\left(\Delta H_{r}\right) X_{A} k_{1} C_{A}\left(1-X_{A}\right)
$$

\subsection{Heating Jacket Design}

\subsubsection{Mass Flow Rate of Heating Fluid}

$$
\dot{m}_{w}=\frac{Q}{C_{p w} \Delta T}
$$

Where: $\Delta T=T_{1}-T_{2}$

\subsubsection{Jacket Dimension}

Height of jacket:

$$
H_{j}=\frac{H_{R}}{2}
$$

Let the pitch $\left(P_{j}\right)$ between the spiral baffles be $0.2 \mathrm{~m}$

Numbers of Spiracles:

$$
N_{s}=\frac{H_{j}}{P_{j}}
$$

Length of Jacket:

$$
L_{j}=N_{s} \pi D_{R}
$$

\subsubsection{Velocity through Channel $(u)$ :}

$$
u=\frac{\dot{m}_{w}}{\rho A_{j}}
$$

\subsubsection{Film Heat Transfer Coefficient for the Jacket} Reynolds number $(\mathrm{Re})$ :

$$
\operatorname{Re}=\frac{\rho u d_{e}}{\mu}
$$

Prandtl number (Pr):

$$
\operatorname{Pr}=\frac{C_{p} \mu}{k}
$$


Where: $\frac{h_{j} d_{e}}{k}=0.023 \operatorname{Re}^{0.8} \operatorname{Pr}^{0.33}$

Overall Heat Transfer Coefficient:

$U_{o}=\frac{h_{j} h_{d}}{h_{j}+h_{d}}$

Where:

$h_{d}=\frac{1}{f_{d}}$

\subsection{Mechanical Design Equations}

\subsubsection{Stirrer Design}

For this work, radial turbine stirrer with 6 blades is used for the two reactors.

Length of $\quad \operatorname{stirrer}\left(L_{s t}\right): \quad L_{s t}=L_{R}-C$

Stirrer clearance $(C): C=\frac{1}{2} t o \frac{1}{6} D_{R}$

Stirrer Diameter $\left(D_{s t}\right): D_{s t}=\frac{1}{2}$ to $\frac{1}{4} D_{R}$

Stirrer blade-width $(W): W=\frac{1}{4} t o \frac{1}{6} D_{s t}$

Wall baffles $(B): B=\frac{1}{10}$ to $\frac{1}{12} D_{R}$

Power consumption $(P)$ [10]: $N_{p}=\frac{P}{n^{3} D^{5}{ }_{s t} \rho}$

Where $N_{p}=f\left(\operatorname{Re}, F r, S_{1}-S_{n}\right)$

$$
\begin{aligned}
& \operatorname{Re}=\frac{n D^{2}{ }_{s t} \rho}{\mu} \\
& F r=\frac{n^{2} D_{s t}}{g}
\end{aligned}
$$

When $\operatorname{Re}>300$, Froude number becomes a factor to determine power consumption
$\frac{N_{p}}{F r^{m}}=\frac{P}{n^{3} D^{5}{ }_{s t} \rho}$

Where:

$$
m=\frac{a-\log \operatorname{Re}}{b}
$$

Further simplification can be made at low and high Reynolds number;

If $\operatorname{Re}<10$; the flow is laminar and density is no longer a factor then;

$\frac{N_{p}}{\operatorname{Re}}=k_{L}$

Substituting (26) into (22): $N_{p}=k_{L} \frac{n D^{2}{ }_{s t} \rho}{\mu}$

Substituting (24) into (22): $P=k_{L} n^{2} D^{3}{ }_{s t} \mu$

If $\operatorname{Re}>10^{4}$, the flow regime is transitional or turbulent and the power consumption is independent of Reynolds number and viscosity is no longer a factor

$N_{p}=k_{T}$

Substituting (38) into (37):

$P=k_{T} \rho D^{5}{ }_{s t} n^{3}$

3.8.2 Standard Plate Thickness [10]:

$t=\frac{P_{R} D_{R}}{S E_{j}-0.6 P_{R}}+c$

\subsection{Solution Techniques}

\subsubsection{Operational Parameters Flow Rate}

Design production rate $=4,535,929.1 \mathrm{~kg}$ per annum.

From (1.1) and (1.2):132kg. kmol ${ }^{-1}$ Of Pentosan yields $150 \mathrm{~kg} . \mathrm{kmol}^{-1}$ of Pentose, also

$150 \mathrm{~kg} \cdot \mathrm{kmol}^{-1}$ Of Pentose yield $96 \mathrm{~kg} . \mathrm{kmol}^{-1}$ of furfural

Therefore: 4,535,926.1 $\mathrm{kg}$ Of furfural will require $6,236,902.5 \mathrm{~kg}(\mathrm{G})$ of raw feed (Pentosan)

Expressing in $\mathrm{kg} . \mathrm{s}^{-1}$ : 


$$
\frac{6,236,902.5 \mathrm{~kg}}{3600 \times 24 \times 365}=0.197 \approx 0.2 \frac{\mathrm{kg}}{\mathrm{s}}
$$

Molecular weight of Pentosan $(A)$ :

$\mathrm{C}_{5} \mathrm{H}_{8} \mathrm{O}_{4}=(12 \times 5)+(1 \times 8)+(16 \times 4)$

$\mathrm{MM}_{\mathrm{A}}=132 \mathrm{~kg} \cdot \mathrm{kmol}^{-1}$,

$F_{A O}=\frac{G}{M M_{A}}$,

$F_{A O}=\frac{0.2 \mathrm{~kg} / \mathrm{s}}{132 \mathrm{~kg} / \mathrm{kmol}}$

$F_{A O}=1.52 \times 10^{-3} \frac{\mathrm{kmol}}{\mathrm{s}}$

Concentration of feeds: $C_{A O}=\frac{\rho_{A}}{M M_{A}}$

Where:

$$
\begin{gathered}
\rho_{A}=1424 \frac{\mathrm{kg}}{\mathrm{m}^{3}}, \\
C_{A O}=\frac{1424 \mathrm{~kg} / \mathrm{m}^{3}}{132 \mathrm{~kg} / \mathrm{kmol}}, \\
C_{A O}=10.79 \frac{\mathrm{kmol}}{\mathrm{m}^{3}}, \\
C_{A}=C_{A . O}\left(1-X_{A}\right)
\end{gathered}
$$

Where fractional conversion is $95 \%$ :

$$
C_{A}=10.79(1-0.95), C_{A}=0.5395 \frac{\mathrm{kmol}}{\mathrm{m}^{3}}
$$

\begin{tabular}{|c|c|}
\hline PROPERTIES & VALUES \\
\hline Molar Mass & $96.08 \mathrm{gmol}^{-1}$ \\
\hline Appearance & Colourless oily \\
\hline Odour & Almond-like \\
\hline Density & $1.16 \mathrm{~g} \cdot \mathrm{ml}^{-1}$ at $20^{\circ} \mathrm{C}$ \\
\hline Melting Point & $-37^{\circ} \mathrm{C},\left(-35^{\circ} \mathrm{F}, 236 \mathrm{~K}\right)$ \\
\hline Boiling Point & $162^{\circ} \mathrm{C},\left(324^{\circ} \mathrm{F}, 435 \mathrm{~K}\right)$ \\
\hline Solubility in water & $83 g \cdot L^{-1}$ \\
\hline Flash Point & $62 \mathrm{oC}, 144^{\circ} \mathrm{F}, 335 \mathrm{~K}$ \\
\hline $\mathrm{LD}_{50}$ (toxicity) & $300-500 \mathrm{mg}^{2} \mathrm{~kg}^{-1}$ (oral, mice) \\
\hline Viscosity $\pi^{20}{ }_{D}$ & 1.49 \\
\hline Oxygen content. \% & $33 \%$ \\
\hline Freezing point & $-37.6^{\circ} \mathrm{C}$ \\
\hline $\begin{array}{l}\text { Auto-ignition } \\
\text { temperature }\end{array}$ & $392^{\circ} \mathrm{C}$ \\
\hline $\begin{array}{l}\text { Partial heat of solution } \\
\text { in water }\end{array}$ & +2988 Cal.mole $^{-1}$ \\
\hline Refractive index & $\begin{array}{l}\text { At } 20 \circ \mathrm{oC} 1.5261 \\
\text { At } 25 \mathrm{oC} 1.5235\end{array}$ \\
\hline Density, $\mathrm{d}_{4}$ at $20^{\circ} \mathrm{C}$ & $1.1598 \mathrm{~g} \cdot \mathrm{cm}^{-3}$ \\
\hline Vapour Density & 3.3 \\
\hline Heat of vaporization & $42.8 \mathrm{Kj} \cdot \mathrm{mol}^{-1}$ \\
\hline Heat Capacity & 1.74J.gk \\
\hline Heat of combustion & $2344 \mathrm{Kj} \cdot \mathrm{mol}^{-1}$ \\
\hline Surface tension & $40 \mathrm{MN} / \mathrm{M}$ \\
\hline $\begin{array}{l}\text { Dielectric constant at } \\
20^{\circ} \mathrm{C}\end{array}$ & 41.9 \\
\hline Explosion Limits & $2.1-19.3$ \\
\hline
\end{tabular}

\section{Pressure of Reactor}

$$
\begin{gathered}
P_{R}=0.01079 \frac{\mathrm{kmol}}{\mathrm{dm}^{3}} \times 0.082 \mathrm{~atm} \frac{\mathrm{dm}^{3}}{\mathrm{kmolK}} \times 448 \mathrm{~K} \\
P_{R}=0.4 \mathrm{~atm}+1 \mathrm{~atm}=1.4 \mathrm{~atm}
\end{gathered}
$$

\section{Kinetic Parameters:}

Table 1: Physical properties data [12], [13]

Table 2: Kinetics parameters for the production of furfural [3]

\begin{tabular}{|l|l|l|}
\hline $\begin{array}{l}\text { Pre- } \\
\text { exponential } \\
\text { value }\left(\mathbf{A}_{\mathbf{O}, \mathbf{i}}\right) \\
\left(s^{-1}\right)\end{array}$ & $\begin{array}{l}\text { Activation } \\
\text { energy }\left(\mathbf{E}_{\mathbf{A}, \mathbf{0}}\right) \\
\left(\frac{\mathrm{J}}{\mathrm{kmol}}\right)\end{array}$ & $\begin{array}{l}\text { Reaction order } \\
\text { of the } \\
\text { hydronuim } \\
\text { concentration } \\
\text { in the acid }\left(\mathbf{m}_{\mathbf{i}}\right)\end{array}$ \\
\hline $3.27 \times 10^{14}$ & 137,300 & $\mathbf{1 . 8 5}$ \\
\hline $1.608 \times 10^{22}$ & 211,300 & $\mathbf{0 . 0 6}$ \\
\hline
\end{tabular}

Taking the temperature of the reaction $175^{\circ} \mathrm{C}$ :

$$
T=175^{\circ} C \approx 448 K
$$

Hydronuim ion concentration as $0.3 \%:\left[H^{+}\right]=0.03$

$$
\begin{aligned}
& R=8.314 \frac{J}{m o l K}, \\
& k_{1}=4.88 \times 10^{-5} s^{-1}
\end{aligned}
$$




$$
\begin{aligned}
& k_{1}=[0.03]^{1.85} \times 3.27 \times 10^{14} s^{-1} \times e^{\left[\frac{-137,300^{J} / \mathrm{mol}}{8.314^{j} / \mathrm{molK}_{\mathrm{K}}^{\times 448 K}}\right]}, \\
& k_{2}=[0.03]^{0.06} \times 1.608 \times 10^{22} s^{-1} \times \ell^{\left[\frac{-211,300^{\mathrm{J} / \mathrm{mol}}}{8.314^{\mathrm{j}} / \mathrm{mol} \mathrm{K}^{\times 448 K}}\right]} \\
& k_{2}=3.00 \times 10^{-3} s^{-1}
\end{aligned}
$$

\section{Reactor Head Dimension}

Where:

$D_{R}=6 m$,

$H_{H}=\frac{D_{R}}{2}$,

$H_{H}=\frac{6 m}{2}$,

$H_{H}=3 m$,

$V_{H}=\frac{2}{3} \pi\left(r_{R}\right)^{3}$,

$V_{H}=0.67 \times 3.142 \times(3)^{3}$,

$V_{H}=56.8 m^{3}$

Heat generated per unit volume [5], [9]:

$$
q_{R}=\left(\Delta H_{r}\right) X_{A} k_{2} C_{A, O}\left(1-X_{A}\right)
$$

Where: $\Delta \mathrm{H}_{\mathrm{R}}=-277,6 \dot{0} 4,400 \mathrm{~J} \cdot \mathrm{kmol}^{-1}$

$q_{R}=\left(-277,604,400 \frac{\mathrm{J}}{\mathrm{kmol}}\right) \times 0.95 \times 3.0 \times 10^{-3} \mathrm{~s}^{-1} \times 10.79 \frac{\mathrm{kmol}}{\mathrm{m}^{3}}(1-0.95)$

$\mathrm{q}_{\mathrm{R}}=426,8 \dot{3} 7 \cdot 6 \mathrm{~J} \cdot \mathrm{m}^{3} \mathrm{~s}^{-1}$

Mat lab 7.7 is used to solve the design equations to give the functional parameters of the reactor such as Volume of reactor, space velocity, space time and length of reactor.

3.10 Heating Jacket Design [5],[9]

Mass Flow Rate of Heating Fluid

$$
\dot{m}_{w}=\frac{Q}{C_{p w} \Delta T}
$$

Where: $Q=\left(\Delta H_{R}\right) F_{A, O} X_{A}$

$Q=\left(277,604,400 \frac{\mathrm{J}}{\mathrm{kmol}}\right) \times 1.09 \times 10^{-3} \frac{\mathrm{kmol}}{\mathrm{s}} \times 0.95$

$Q=287,459.36 \frac{J}{s} C_{p w}=1.851 \frac{K J}{k g K}$ At $200^{\circ} \mathrm{C}$

The heating fluid enters the jacket at $200^{\circ} \mathrm{C}$ and leaves at $45^{\circ} \mathrm{C}$

$\Delta T=T_{1}-T_{2}$

$\Delta T=200^{\circ} \mathrm{C}-50^{\circ} \mathrm{C}$,

$\Delta T=150^{\circ} C \approx 423 K$,

$\dot{m}_{w}=\frac{287.46 K J / s}{1.851 K J / k g K \times 423 K}$

$\mathrm{m}_{\mathrm{w}}=0 . \dot{3} 7 \mathrm{~kg} \cdot \mathrm{s}^{-1}$

\section{Jacket Dimension}

Height of jacket:

$H_{j}=\frac{H_{R}}{2}$,

$H_{j}=\frac{1.8 m}{2}$

$H_{j}=0.9 m$

Let the pitch $\left(P_{j}\right)$ between the spiral baffles be $0.2 m$

Numbers of spiracles:

$$
\begin{aligned}
& N_{s}=\frac{H_{j}}{P_{j}}, \\
& N_{s}=\frac{0.9 m}{0.2 m}, \\
& N_{s}=4.5 \approx 5
\end{aligned}
$$

Length of Jacket: 


$$
\begin{aligned}
& L_{j}=N_{s} \pi D_{R}, \\
& L_{j}=5 \times 3.142 \times 6 m \\
& L_{j}=94.3 m
\end{aligned}
$$

Area of jacket: Let, the space between the jacket and the reactor be $\Delta b=0.3 m$

$A_{j}=0.3 m \times 0.2 m$

$A_{j}=0.06 m^{2}$

Hydraulic diameter $\left(d_{e}\right)$ :

$d_{e}=\frac{4(0.3 \times 0.2)}{2(0.3+0.2)}$

$d_{e}=0.24 m$

Velocity through channel $(u): u=\frac{\dot{m}}{\rho A_{j}}$

Where; $\rho=1000 \mathrm{~kg} . \mathrm{m}^{3}, \quad u=\frac{0.37 \frac{\mathrm{kg}}{\mathrm{s}}}{1000 \frac{\mathrm{kg}}{\mathrm{m}^{3}} \times 0.06 \mathrm{~m}^{2}}$ $u=6.17 \times 10^{-3} \frac{m}{s}$

\section{Film Heat Transfer Coefficient for the Jacket}

Reynolds number $(\mathrm{Re})$ :

$\operatorname{Re}=\frac{\rho u d_{e}}{\mu}$

$\mu=134.5 \times 10^{-6}$ Pa.s

$\operatorname{Re}=\frac{1000 \times 0.48 \times 0.24}{134.5 \times 10^{-6}}$

$\operatorname{Re}=856505.5$

Prandlts number $(\operatorname{Pr})_{:} \operatorname{Pr}=\frac{C_{p} \mu}{k}$

$$
\begin{aligned}
& \text { Where: } \mathrm{C}_{\mathrm{p}}=1.939 \mathrm{KJ} . \mathrm{kg}^{-1} \mathrm{~K}^{-1} \\
& k=663.31 \times 10^{-3} \frac{\mathrm{W}}{m . K} \\
& \operatorname{Pr}=\frac{1.939 \times 134.5 \times 10^{-6}}{663.31 \times 10^{-3}}
\end{aligned}
$$

$\operatorname{Pr}=0.39$

$\frac{h_{j} d_{e}}{k}=0.023 \operatorname{Re}^{0.8} \operatorname{Pr}^{0.33}$

Ignoring correction factor or taking it as 1

$$
\begin{aligned}
& \frac{h_{j} \times 0.24}{663.31 \times 10^{-3}}=0.023(856505.5)^{0.8}(0.39)^{0.33} \\
& \mathrm{~h}_{\mathrm{j}}=2597 \mathrm{~W} . \mathrm{m}^{-2} \mathrm{~K}^{-1}
\end{aligned}
$$

\section{Overall Heat Transfer Coefficient}

$U_{o}=\frac{h_{j} h_{d}}{h_{j}+h_{d}}$

Where;

$$
h_{d}=\frac{1}{f_{d}}
$$

Where,

$$
f_{d}=0.0025 \frac{m^{2^{\circ}} C}{W}
$$

$$
\begin{aligned}
& h_{d}=\frac{1}{0.0025} \\
& h_{d}=400 \frac{W}{m^{2^{\circ} C}} \\
& \therefore \frac{1}{U_{o}}=\frac{1}{2597}+\frac{1}{400} \\
& U_{o}=346.62 \frac{W^{-2} C^{-1}}{m^{-25}}
\end{aligned}
$$

Heat Transfer Area of the Jacket

$$
A=\frac{Q}{U_{o} \Delta T_{l m}}
$$


Take the log mean temperature as arithmetic mean of the temperatures.

$\Delta T_{l m}=\frac{200+50}{2}$

$\Delta T_{l m}=125^{\circ} \mathrm{C}$

$$
A=\frac{287,459.36 \frac{\mathrm{J}}{\mathrm{s}}}{346.62 \frac{W}{\mathrm{~m}^{-2} \mathrm{C}^{-1}} \times 125^{\circ} \mathrm{C}}
$$

$A=6.63 m^{2}$

\section{Mechanical Design Aspect of the Reactor[1]}

\section{Stirrer Design}

Stirrer clearance $(C)$ :

$$
C=\frac{1}{6} D_{R}
$$$$
C=\frac{6 m}{6}
$$$$
C=1.0 m
$$

Stirrer length $\left(L_{s t}\right)$

$$
\begin{aligned}
& L_{s t}=H_{R}-C \\
& L_{s t}=1.8 m-1.0 m \\
& L_{s t}=0.8 m
\end{aligned}
$$

Diameter of stirrer $\left(D_{s t}\right)$

$$
D_{s t}=\frac{D_{R}}{4}
$$$$
D_{s t}=\frac{6 m}{4}
$$

$$
D_{s t}=1.5 m
$$

Stirrer blade width $(W)$

$$
W=\frac{D_{s t}}{5}
$$

$W=\frac{1.5 m}{5}$

$W=0.3 m$

Wall baffle

$W=\frac{D_{R}}{10}$

$W=\frac{6 m}{10}$

$W=0.6 m$

Power consumption

$\operatorname{Re}=\frac{n D^{2}{ }_{s t} \rho}{\mu}$

Using the viscosity of water since the mixture is water-base; $\rho=1424 \mathrm{~kg} \cdot \mathrm{m}^{3}$

$W=1791.2 \times 10^{-6}$ Pa.s

Taking $n=90 r / \min$

The stirrer type is a radial turbine with 6 blades

$\operatorname{Re}=\frac{90 / 60 \times(1.5)^{2} \times 1424}{1.7912 \times 10^{-2}}$

$\operatorname{Re}=2,683,117.46$

Since $\operatorname{Re}>10^{4}$, the flow regime is turbulent and the power consumption is independent of the Reynolds number.

$N_{P}=K_{T}$

Where $K_{T}=6.30$ (Peters M.S, 2004)

$P=K_{T} \rho D^{5}{ }_{s t} n^{3}$

$P=6.30 \times \frac{1424}{1000} \times(1.5)^{5} \times(90 / 60)^{3}$

$P=0.229 K W \approx 0.23 K W$ 


\section{Standard Plate Thickness}

$$
\begin{aligned}
& t=\frac{P_{R} D_{R}}{S E_{j}-0.6 P_{R}}+c \\
& p_{R}=1.4 \mathrm{~atm} \times 1.013 \times 10^{5} \mathrm{Nm}^{-2}=141,855 \mathrm{pa} \\
& D_{R}=6 \mathrm{~m} \\
& S=66,900 \times 10^{3} \mathrm{pa} \\
& E_{j}=0.6 \\
& c=0.0032
\end{aligned}
$$$$
t=\frac{141,855 \times 6 m}{66,900 \times 10^{3} \times 0.6-0.6 \times 141,855}+0.0032
$$$$
t=0.024 m
$$

\section{Material Selection [1]}

Based on the following factors;

Corrosion resistant

Temperature

Allowable pressure

Mechanical properties such brittleness, low thermal conductivity.

$\mathrm{PH}$

Heat transfer rate

Austenitic stainless steel is selected as the material for constructing and fabrication of the reactor.

Carbon steel is selected for the heating jacket

\section{Costing of the Reactor[10]}

Using the correlation chart, the purchase cost is $\$ 70,000$. In Nigeria equivalent at the exchange rate of 150 naira to $\$ 1$, The purchase cost is $10,500,000$ naira.

\section{RESULTS AND DISCUSSION}

Mat lab (7.7) was used to simulate the reactors parameters and the results presented on graphs.

The discussion is on the graphs plotted with result of simulation using Mat lab. The graphs are;

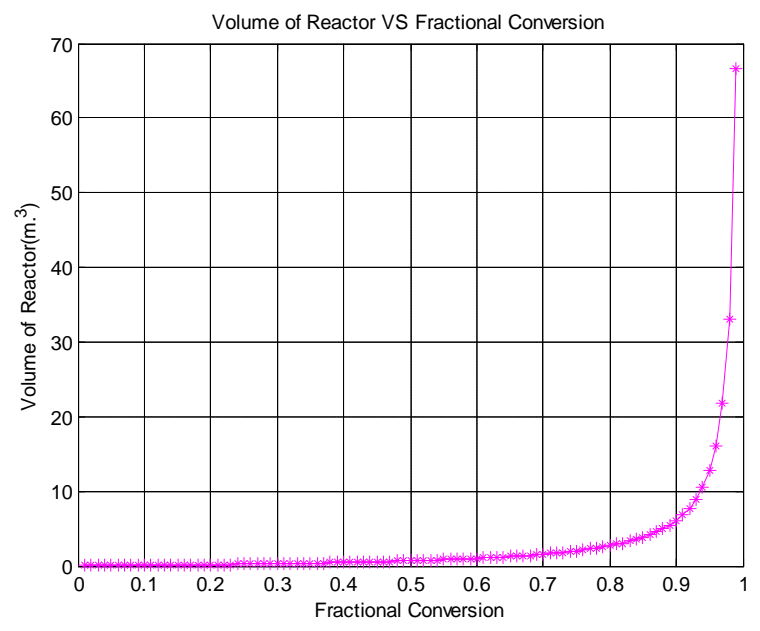

Fig 1 plot of volume of reactor against fractional conversion

The plots shows that volume of the reactor increases slowly at different fractional to a point where there is a rise in the volume increase till it gets to infinity.

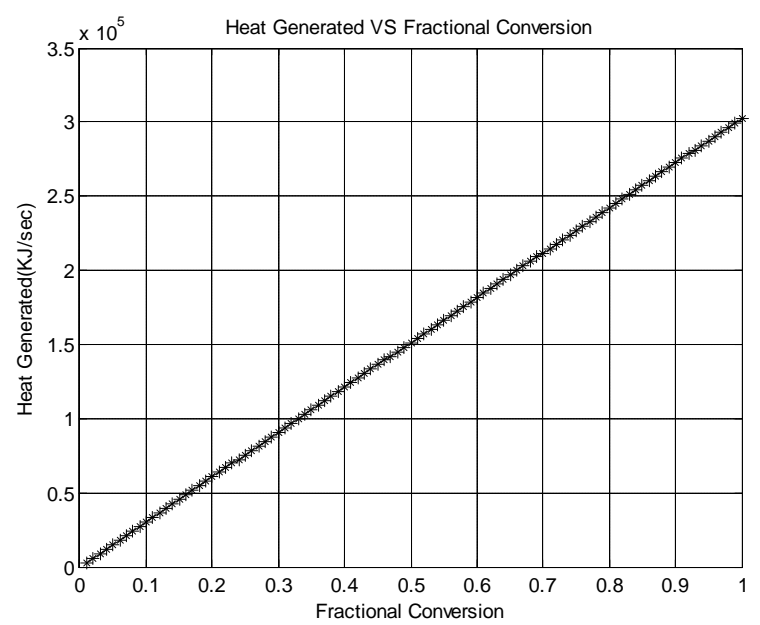

Fig 2 plot of heat generated against fractional conversion

The graph gives a straight line negative graph which shows that the heat generated is directly proportional to fractional conversion

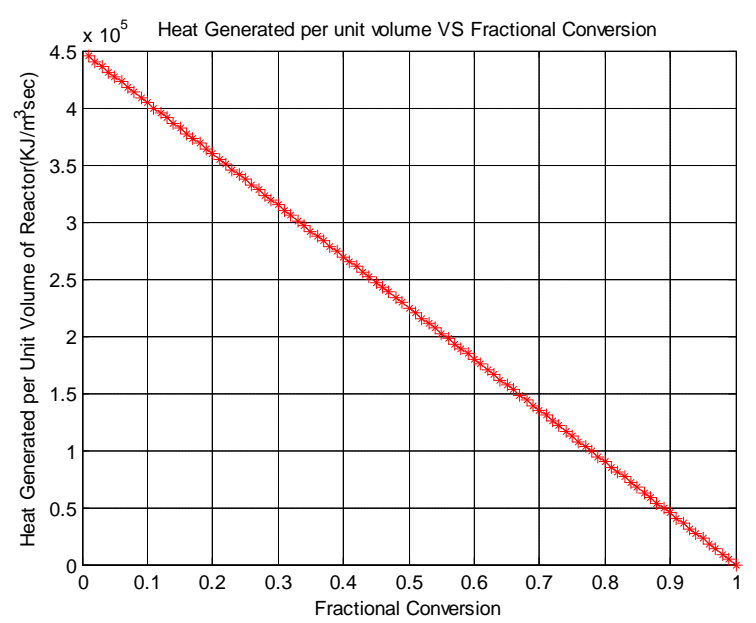

Fig 3 plot of Heat generated per unit volume against fractional conversion 
The graph gives a negative straight line graph which shows that the heat generated is directly proportional to fractional conversion

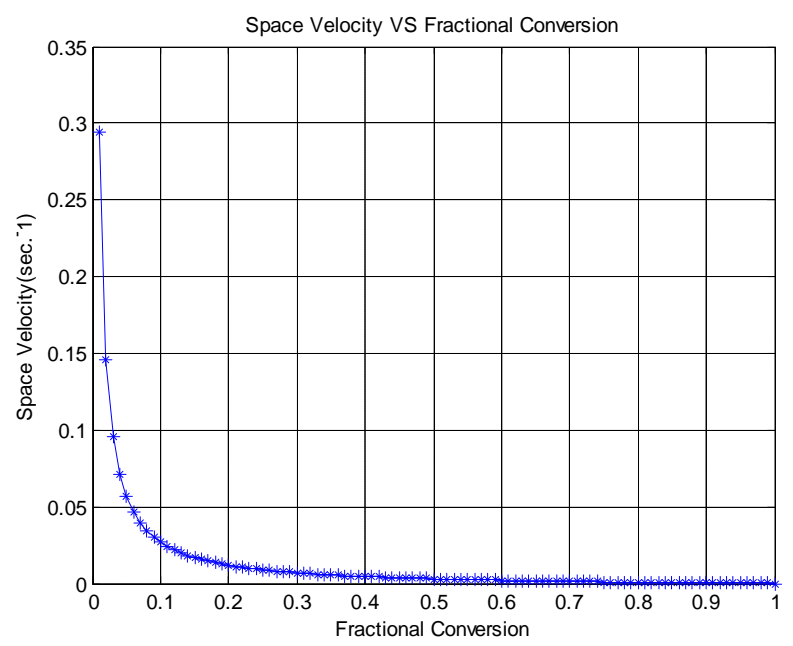

Fig 4 Plot of space velocity against fractional conversion

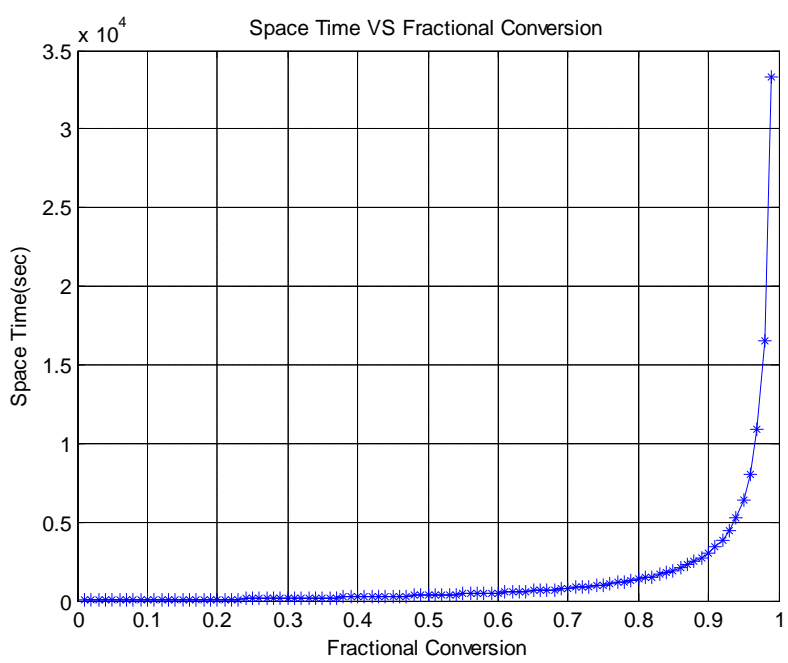

Fig 5 plot of space time against fractional conversion The graph shows that the time taken to react one reactor volume of feed increases with the fractional conversion slowly to a point, it increases till it goes to infinity.

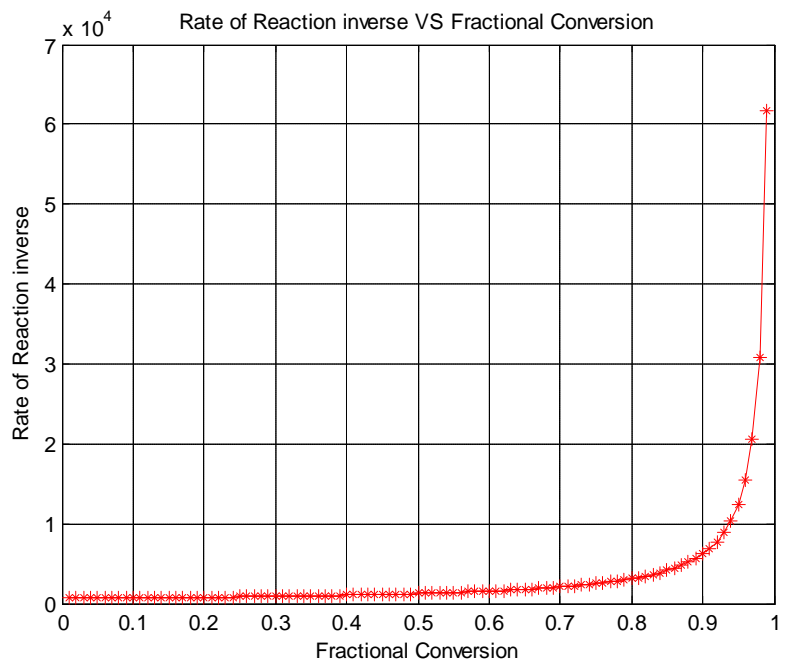

Fig 6 plot of rate inverse against fractional conversion
The graph for the reactor shows a steady rate till a point the rate starts to reduce till it gets to infinity. The graph can be use as a model to determine the volume of the reactor at any fractional conversion. This is done by multiplying the flow rate by the area under the curve from the point of the required fractional conversion.

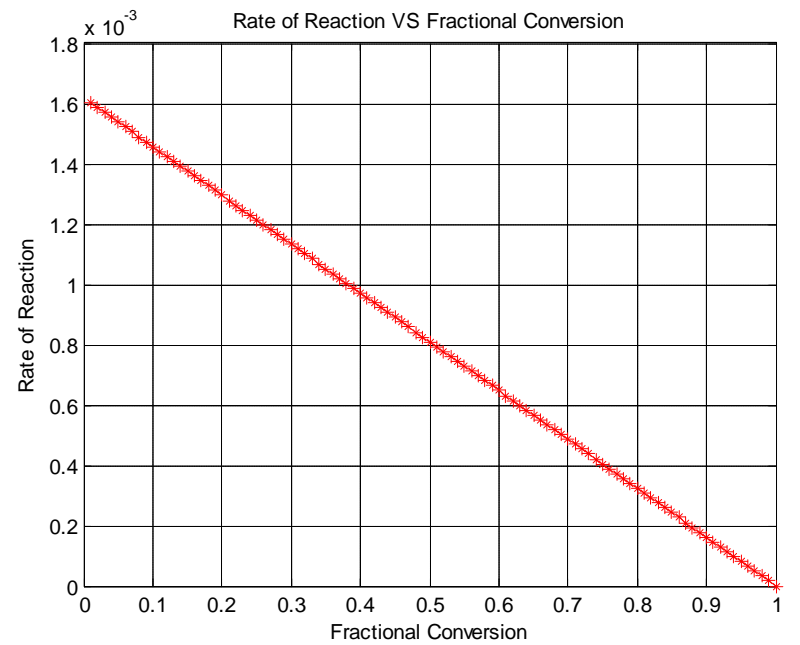

Fig 7 Plot of Rate of reaction against fractional conversion

The plot of rate of reaction against fractional conversion for the reactor produced a negative straight line graph which shows that the rate of reaction is directly proportional to fractional conversion.

\section{CONCLUSION}

The design process accommodates the general principles of material and heat balances, rate law, kinetics, economics and mechanical aspects to bring to bear the designing of the CSTR of capacity. This is a typical pragmatic design that can be operationalised by private sector.

\section{NOMENCLATURE}

$\Delta=$ Heat

$\mathrm{K}_{1}, \mathrm{k}_{2}=$ Rate constant

$\mathrm{r}_{\mathrm{xylan}}=$ Rate of xylan hydrolysis

$r_{\text {xylosee }}=$ Rate of xylose dehydration

$r_{\text {furfural }}=$ Rate of furfural hydrolysis

$\mathrm{C}_{\mathrm{A}}=$ Final concentration of $\mathrm{A}$

$\mathrm{C}_{\mathrm{B}}=$ Final concentration of $\mathrm{B}$

$\mathrm{C}_{\mathrm{C}}=$ Final concentration of $\mathrm{C}$

$\mathrm{C}_{\mathrm{AC}}=$ Initial concentration of $\mathrm{A}$

$\mathrm{C}_{\mathrm{BO}}=$ Initial concentration of $\mathrm{B}$

$\mathrm{C}_{\mathrm{CO}}=$ Initial concentration of $\mathrm{C}$

$\mathrm{t}=$ Time

$\mathrm{A}_{\mathrm{Oi}}=$ Pre-exponential factor

$\mathrm{E}_{\mathrm{Ai}}=$ Activation energy

$\mathrm{R}=$ Gas constant

$\mathrm{T}=$ Temperatue

$\mathrm{F}_{\mathrm{iO}}=$ Initial molar flow rate of specie $\mathrm{i}$

$\mathrm{X}_{\mathrm{i}}=$ Fractional conversion of specie $\mathrm{i}$

$\mathrm{V}_{\mathrm{R}}=$ Volume of reactor

$\mathrm{r}_{\mathrm{i}}=$ Initial concentration of $\mathrm{C}$

$\mathrm{V}_{\mathrm{R}}=$ Volume of reactor 
$\mathrm{F}_{\mathrm{AO}}=$ Initial molar flow rate of specie

$\pi=$ Pie

$\mathrm{r}=$ Radius

$\mathrm{L}_{\mathrm{H}}=$ Length of reactor

$\mathrm{V}_{\mathrm{H}}=$ Volume of reactor head

$\mathrm{L}=$ Length

RTD $=$ Resident Time Distribution

$\tau=$ Space

$\mathrm{S}_{\mathrm{V}}=$ Space velocity of reactor

$\mathrm{q}_{\mathrm{R}}=$ Heat generated per unit volume of reactor

$\mathrm{L}_{\mathrm{ST}}=$ Length of stirrer

$\mathrm{C}=$ Clearance of stirrer

$\mathrm{D}_{\mathrm{St}}=$ Diameter of stirrer

$\mathrm{B}=$ Wall baffle

$\mathrm{P}=$ Power

$\mathrm{N}_{\mathrm{P}}=$ Power number

$\mathrm{n}=$ Number of revolution

$\rho=$ Density

$\mathrm{f}=$ Function

$\mathrm{R}_{\mathrm{e}}=$ Reynold number

$\mathrm{f}_{\mathrm{r}}=$ Froude number

$\mathrm{S}_{\mathrm{n}}=$ Reactor dimension number

$\mu=$ Viscosity

$\dot{\mathrm{m}}=$ Mass flow rate

$\Delta \mathrm{H}_{\mathrm{R}}=$ Heat of reaction

$\Delta \mathrm{T}=$ Change in Temperature

$\mathrm{H}_{\mathrm{j}}=$ Height of the jacket

$\mathrm{L}_{\mathrm{j}}=$ Length of the jacket

$\mathrm{P}_{\mathrm{j}}=$ Pitch of the spiracles

$A_{j}=$ Area of heating jacket

$\mathrm{d}_{\mathrm{e}}=$ Hydraulic diameter

$\mathrm{u}=$ Velocity

$\mathrm{Pr}=$ Prandlt number

$\mathrm{k}=$ Thermal conductivity

$h_{j}=$ Film heat transfer of the heating jacket

$h_{d}=$ Film heat transfer coefficient of dirt

$\mathrm{f}_{\mathrm{d}}=$ Dirt factor

$\mathrm{U}_{\mathrm{o}}=$ Overall transfer coefficient

$\Delta \mathrm{T}_{\mathrm{lm}}=$ Log mean temperature

\section{REFERENCES}

[1]. Bhattachanyya B.C, (2005) "Introduction to chemical equipment design (Mechanical aspect)" $1^{\text {st }}$ Edition, CBS, New Delhi. PP 29, 39, 246.

[2]. Dimian C.A, (2005) "Integrated Design and Simulation of chemical processes", volume 13, $1^{\text {st }}$ Edition, Elsevier Inc. USA page. 127.

[3]. Dussan K., Girisuta B., Haverty D., Leachy J.J., Hayes M.H.B "kinetics of levulinic acid and furfural production from miscanthus x giganteus". Bioresources technology. Page 24

[4]. Joseph B. B (2010) "Synthesis of furfural from xylose and xylan". Chemsuschem energy and materials 1268-1278. [5]. Kern, D.Q, (2006) "Process heat transfer", $1^{\text {st }}$ edition, McGraw-hill, USA Page 127.

[6]. Manuel A.V., Robeiro da silva, Maria D.M.C., (2012). Thermochemistry of D-xylose. Journal of chemical thermodynamics. 58(2013). Pp 20-28
[7]. Marcotullio G, (2005) "The chemistry and technology of furfural production in modern lignocelluloses-feedstock bio-refineries", Arkh Edisioni, Rome. pp 10, 15, 20

[8]. Nevers N, (2005) "Fluid mechanics for chemical engineers" $3{ }^{\text {rd }}$ Edition, McGraw-Hill, Singapore. Page 565

[9]. Octave L, (2001) "Chemical reactions engineering" $3^{\text {rd }}$ edition, Wiley, New Delhi. Pp 84, 85, 86 Page 127.

[10]. Peter M.S, Timmerhans D.K, West E.R, (2004)"Plant Design and economic for chemical engineers" 5 th edition, McGraw-Hill, Singapore. PP 536, 539, 597.

[11]. Smith R, (2008) "Chemical process design and integration", $3^{\text {rd }}$ edition, Wiley, Singapore. Pp 78, 97

[12]. H. E. Hoydonckx, W. M. Van Rhijn, W. Van Rhijn, D. E. De Vos, P. A. Jacobs "Furfural and Derivatives" in Ullmann's Encyclopedia of Industrial Chemistry 2007, Wiley-VCH,

Weinheim. doi:10.1002/14356007.a12_119.p029

[13]. Perry and Green, (1998); Perry's Chemical Engineers Handbook, $7^{\text {th }}$ ed., McGraw Hill, New York, PP. 23-4, 5.

\section{BIOGRAPHY}

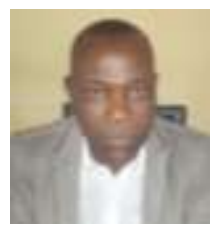

Animia A. Wordu (PhD) was a Senior Process Technologist with many years of industrial experience with the Port Harcourt Refining Company, Alesa - Eleme, Port Harcourt, Nigeria; before going for his Doctorate degree with the Rivers State University of Science and Technology, Nkpolu, Port Harcourt, Nigeria. After completion of $\mathrm{PhD}$, was retained as a Lecturer 1 with the Department of Chemical/ Petrochemical Engineering. His researches are majorly tailored to the Process Industry especially Reactors and Chemical Engineering Thermodynamics. 